\title{
Effect of Folic Acid, N-acetyl Cysteine and Insulin and Their Combinations on Uterine Histology Alloxan Induced Diabetic Pregnant Rats and Their Fetuses
}

\author{
Lana Sardar Salih \\ Department of Bilogy / College of Science \\ University of Salahadiin \\ Kusai A .Al-Chaladi \\ Hamad Jandari Jamma \\ Department of Bilogy / College of Science \\ University of Mosul
}

Received

10 / 09 / 2009
Accepted

$16 / 02 / 2010$

\section{الخلاصة}

أجريت هذه الدراسة لمعرفة تأثيرات حامض الفوليك والاستايل سستين والانسولين على العي

التراكيب النسجية في ارحام الجرذان الحبلى والمحدث فيها داء السكري بالالوكسان واجنتها.

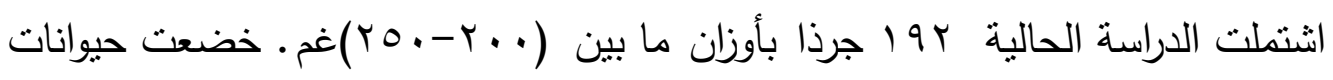

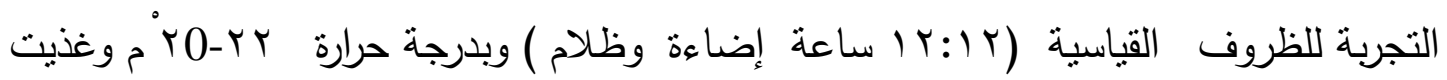
الحيوانات على الغذاء التقليدي للجرذان. تم تزويج إناث الجرذان مع ذكور أصحاء وحدد أول يوم من الحمل بوساطة

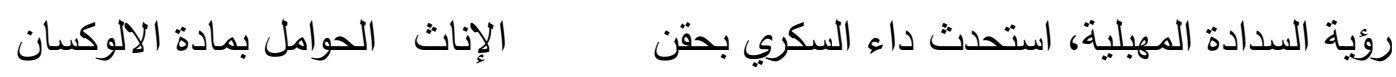
بتركيز ( . (1 ملغم /كغم ) وزن الجسم عن طريق تحت الجلد وتم قياس مستوى كلوكوز

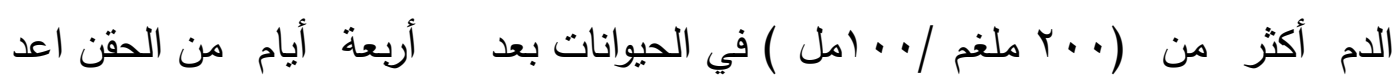

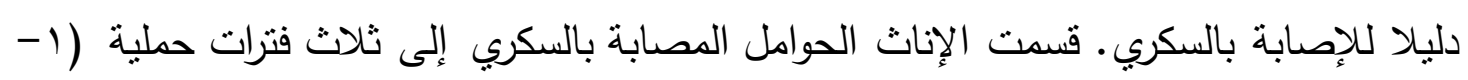

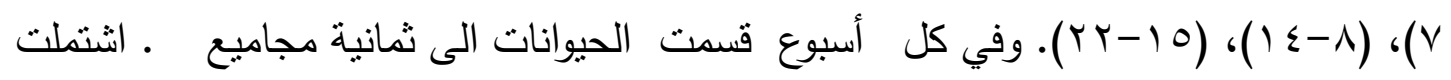

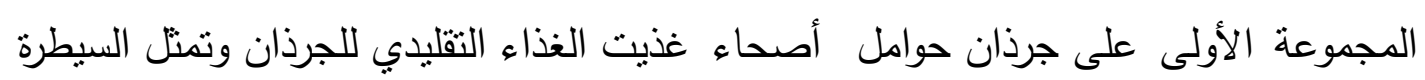

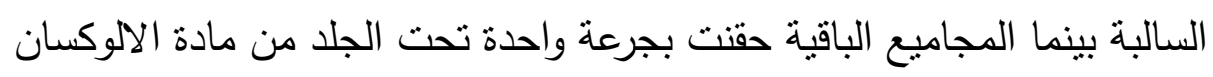

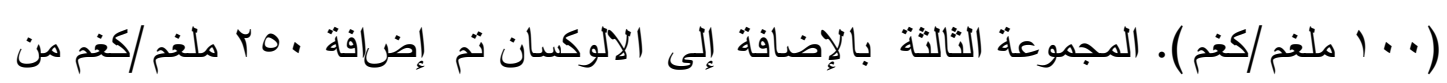

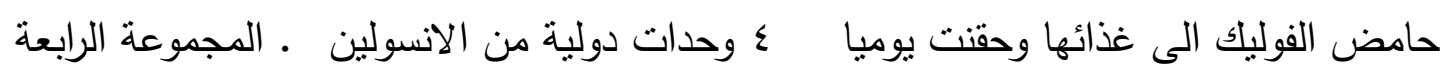




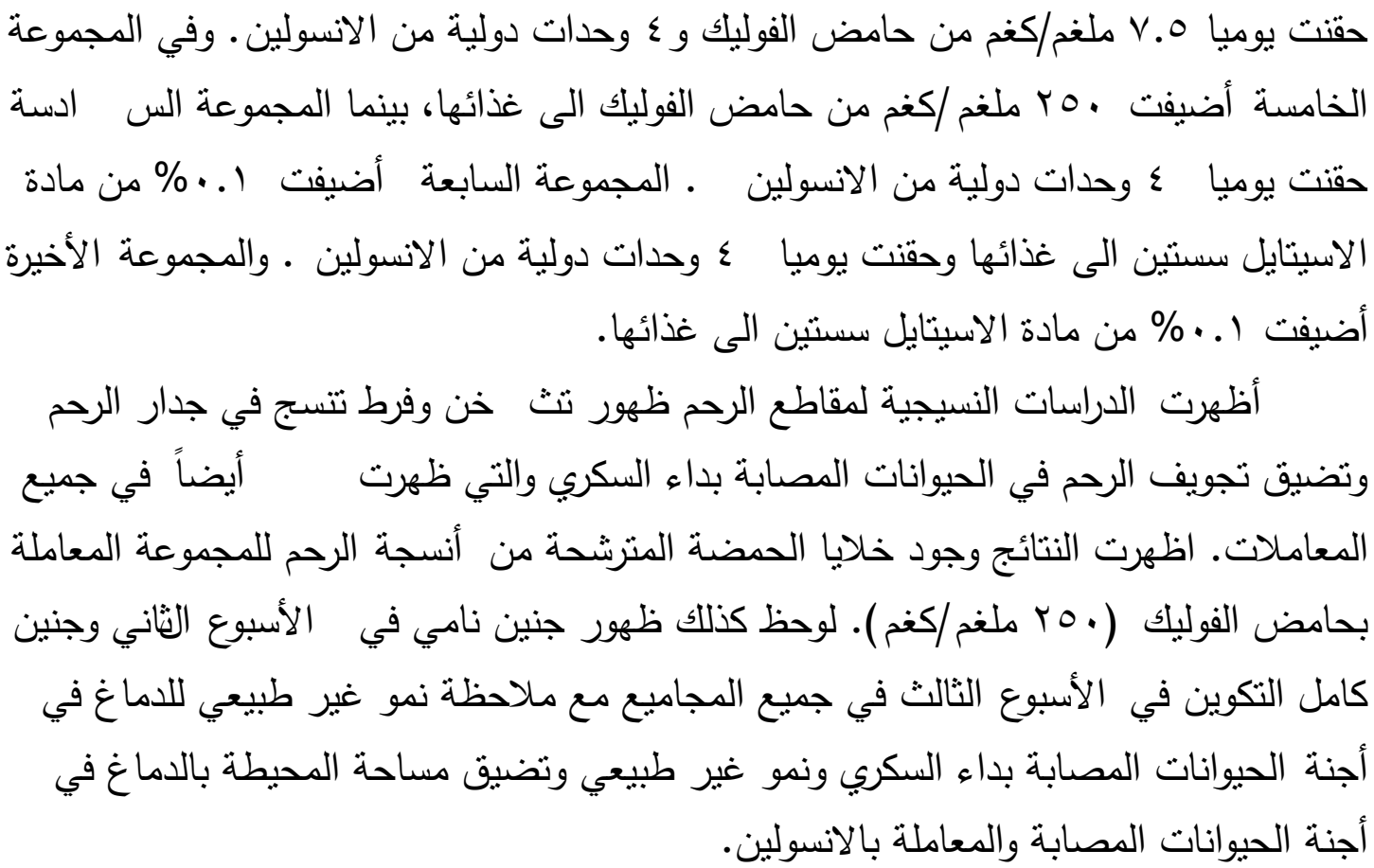

\section{Abstract}

This study has been carried out to assess the effect of folic acid, Nacetyl Cysteine and insulin on some histological parameters in the uterus of alloxan induced diabetic rats and their fetuses.

In this study, 192 healthy pregnant rat, whose weight was about 200-350grams were used.The animals were housed under standard laboratory condition ( $12 \mathrm{~h}$ light; $12 \mathrm{~h}$ dark at 20-24 $\left.\mathrm{C}^{\circ}\right)$. The animals were given standard rat pellets and tap water ad libtium.

Normal female rats mated with normal males, then the first day of gestation were detected through vaginal plug. Diabetes mellitus were induced by a single subcutaneous injection of $100 \mathrm{mg} / \mathrm{kg}$ of alloxan. After four days, rats which showed blood glucose of more than $200 \mathrm{mg} / \mathrm{dl}$ were considered as alloxan induced diabetic pregnant, and they were distributed to three periods (1-7, 8-14 and 15-22 days) of gestation. Diabetic pregnant rats at each period were divided into eight subgroups groups. First subgroup supplemented with standard diet which represent the negative control, while the rest subgroups were treated with $100 \mathrm{mg} / \mathrm{kg}$ alloxan. In addition to alloxan, the third subgroup were treated with $250 \mathrm{mg} / \mathrm{kg}$ folate and $4 \mathrm{I} . \mathrm{U}$.insulin, the subgroup four was daily injected with $7.5 \mathrm{mg} / \mathrm{kg}$ folate and 4 I.U. insulin, the subgroup five was supplemented with $250 \mathrm{mg} / \mathrm{kg}$ folate, subgroup six was daily injected with 4 I.U. insulin, subgroup seven was supplemented with $0.1 \% \mathrm{~N}$-acetyl cysteine and 4 I.U .insulin and the rats of the last group were supplemented with $0.1 \% \mathrm{~N}$-acetyl cysteine. 
Histological examination of uteri sections revealed thickness and of uterine wall hyperplasia and stenation of the uterine mucosa in all treated groups during the first week of gestation .Infiltration of the uterine wall with eosinophilic cells were seen in folic acid $(250 \mathrm{mg} / \mathrm{hg})$ treated subgroup.Growing embryos were seen during the second week of gestation and full grown embryos were seen during the third week of gestation in all treated groups. Abnormal development brain seen in fetuses of diabetic rats. Also abnormal and restricted of peripheral area around the brain were seen in insulin treated rats.

\section{Introduction}

Diabetes complicates 2-3\%of all pregnancies, and despite major advances in clinical management, prenatal morbidity and complications remains significant during pregnancy. Insulin-dependent (type I) diabetes mellitus is characterized always a layer by elevated blood glucose levels brought about by a deficiency in insulin production. This elevation of glucose results in serious pathological complications; pregnancy diabetics often suffer from reproductive problems, such as spontaneous abortion, neonatal morbidity and mortality, and congenital malformations (1).

Work with diabetic animal models has demonstrated uterine atrophy, reduced mating ability and alterations of the hypothalamichypothalamo-hypophyseal ovarian axis. Type I diabetes also affects ovarian function $(1,2)$.

Hyperglycemia has been proposed to be a major contributing factor in the development of many of the complications of diabetes during pregnancy, in particular accelerated fetal growth.Because of the facilitative nature of transplacental glucose transport, maternal hyperglycemia results in elevated fetal glucose levels, which in turn stimulates fetal insulin release.Type 1 diabetes suggests a complex relationship between metabolic disturbance and fetal growth during pregnancy (3).

The teratological processes in diabetic pregnancy are not completely understood.In recent years, however, a putative excess of reactive oxygen species (ROS) has been observed in studies during which diabetes-induced embryopathy was blocked by antioxidants in vitro and vivo (4).

\section{The aims of study:}

Since oxidative stress is an important pathway for fetal injury, we examine in alloxan induced diabetic pregnant rats embryopathy whether folic acid and n-acetyl cysteine supplementation would affect the teratological impact of maternal diabetic in vivo. 


\section{Materials and Methods}

Adult female albino rats Rattus norvegicus bred in the animal house of Biology Dept/.College of science/University of Salahaddin.192 healthy pregnant rats weight about (200-250) gram were used in this study .The animals were housed in plastic cages bedded with wooden chips . The animals were housed under standard laboratory conditions 12 $\mathrm{h}$ light :12 h dark photoperiod, 20-24 $\mathrm{C}^{\circ}$, (5). The animals were given standard rat pellets and tap water ad libitum.

Diabetes was induced by a single subcutaneous injection of 100 $\mathrm{mg} / \mathrm{kg}$ body weight of alloxan monohydrate (BDH Chemical Ltd . England) dissolved in citrate buffer $(\mathrm{pH}=4.5)$ immediately before injection. The control animals received citrate buffer only (6). Alloxan treated animals were allowed to drink $5 \%$ of D-Glucose (Merck KGG, a Damstadt Germany) overnight to prevent the potentially fatal hypoglycemia occurring as a result of massive insulin release following alloxan injection (7). Diabetes mellitus was confirmed in rats by testing for blood glucose level using indicator sticks (Accu-check Roche Dignostics $\mathrm{GmbH}$, Manahem, Germany) and the rats were considered as alloxan induced diabetes rats (8). Symptoms of diabetes were observed within three days of alloxan injection.

The period of gestation was about 22 days, which was subdivided into three periods (1-7, 8-14 and 15-22 days).

\section{Design of experiment:}

In all subgroups, normal female rats about $200-250 \mathrm{~g}$ body weight mated with normal male. Then 0 day of gestation was detected by vaginal plug detection, and then divided to eight subgroups for each week:

\begin{tabular}{|c|c|c|c|c|}
\hline & $\mathrm{NAC}$ & Folate & Insulin & Alloxan \\
\hline Control negative & - & - & - & - \\
\hline Control positive & $100 \mathrm{mg} / \mathrm{kg}$ & - & - & - \\
\hline $\begin{array}{c}\text { Folate } \\
(250 \mathrm{mg} / \mathrm{kg})+\text { insulin }\end{array}$ & $100 \mathrm{mg} / \mathrm{kg}$ & $4 \mathrm{IU} / \mathrm{kg} /$ day & $\begin{array}{c}250 \mathrm{mg} . \mathrm{kg} \\
\text { with diet }\end{array}$ & - \\
\hline $\begin{array}{c}\text { Folate } \\
\left(\begin{array}{c}7.5 \mathrm{mg} / \mathrm{kg} / \mathrm{day})+ \\
\text { insulin }\end{array}\right.\end{array}$ & $100 \mathrm{mg} / \mathrm{kg}$ & $4 \mathrm{IU} / \mathrm{kg} /$ day & $\begin{array}{c}7.5 \\
\text { mg/kg/day } \\
\text { injection }\end{array}$ & - \\
\hline Folate & $100 \mathrm{mg} / \mathrm{kg}$ & - & $\begin{array}{c}250 \mathrm{mg} . \mathrm{kg} \\
\text { with diet }\end{array}$ & - \\
\hline Insulin & $100 \mathrm{mg} / \mathrm{kg}$ & $4 \mathrm{IU} / \mathrm{kg} /$ day & - & - \\
\hline NAC+insulin & $100 \mathrm{mg} / \mathrm{kg}$ & $4 \mathrm{IU} / \mathrm{kg} /$ day & - & $0.1 \%$ \\
\hline NAC & $100 \mathrm{mg} / \mathrm{kg}$ & - & - & $0.1 \%$ \\
\hline
\end{tabular}

At the end of each experiment, the rats were anesthetized with ketamine hydrochloride $100 \mathrm{mg} / \mathrm{kg}$. Uterine samples were removed from the anesthetized animal. All samples were processed for light microscopy by embedding in Bouin's solution (70 ml of picric acid, $30 \mathrm{ml}$ of $10 \%$ formalin and $5 \mathrm{ml}$ of glacial acetic acid) $(9 \& 10)$. 


\section{Results and Discussion}

The uteri of alloxan treated pregnant rats during the first week of gestation showed enlargement due to deposition of fibrous tissue which leads to narrowing of the uterine cavity (Fig. 1). It has been shown that pregnant diabetes women have thicker endometrium than that of a healthy women (11). In this study the embryos at early stage of development were seen implanted in the uterine wall. These results in consistence with Padmanabhan and Shafiullah, (2001) (12) who has found perivascular fibrosis and eosinophilic mass, which they represent fetal growth retardation in a streptozotocin induced diabetes in rats (control). In comparison, the uteri of normal pregnant rats and for same period showed normal histology, consisting of endometrium, myometrium and serosa (Fig. 2). At the second week of gestation we observed implantation in the uterine wall. In comparison, sections of the uteri of normal pregnant rats showed the presence of thin-walled cavities that represent implantation sites. At the third week of gestation, the uteri showed more mature embryos compared to that of the earlier stages (Fig. 3). Well grown embryo with normal brain observed in uteri of the pregnant normal rats (Fig. 4).

Examined sections of the uteri of pregnant diabetic rats that were treated with folic acid $(250 \mathrm{mg} / \mathrm{kg})$ and insulin, during the first week of gestation showed extensive hyperplasia of the epithelium in the endometrium with heavy infiltration of the uterine wall by eosinphilic cells (Fig. 5). At the second week of gestation, narrowing cavity was seen due to epithelial hyperplasia and thickening of the wall of the uterus. Enlargement of uterus or hyperplasia especially in the endometrium during gestation due to elevated hormone levels (13). Growing embryos were seen implanted inside membranes within the uterine wall. Similar changes were seen at the third week of gestation but the embryos, were more mature and well grown (Fig. 6).

Sections of uteri of pregnant diabetic rats that received folic acid $(7.5 \mathrm{mg} / \mathrm{kg})$ and insulin showed narrowing of the uterine cavity at the first week of gestation due to thickening of all layers of the uterine wall. Implanted material was seen in the uterine wall. Similar changes were observed during the second week of gestation and the embryos were seen to be more mature (Fig. 7). At the third week of gestation, there were thickening of the uterine wall, endomaterial hyperplasia and the presence of some tissue debris in the cavity.

The group of pregnant rats which received folic acid during first week of gestation, there were narrowing of uterine cavity, endomaterial hyperplasia and the infiltration of rounded cells in the mucosal layer (Fig. 8). At the second week there were endomaterial hyperplasia, increased thickening of the uterine wall (due to fibrosis), and the presence 
of many embryos embedded in the uterine wall. Similar changes were seen during the third week of this study and embryos were seen to be more grown as indicated by the neural tube.

Sections from the uteri of pregnant diabetic rats treated with insulin alone at the first week of gestation, showed thickening of the uterine wall (due to fibrosis) and narrowing of the uterine cavity. Enlargement of uterus or hyperplasia especially in the endometrium during gestation is probably increased hormone levels (13). At the second week, there was more narrowing of the uterine cavity due to increased thickness of the uterine wall and to congested and engorged blood vessels were evident in the uterine wall (Fig. 9). Fully grown embryos were also seen implanted in the uterine wall at the third week of gestation (Fig. 10).

The uteri which belong to n-acetyl cysteine and insulin treated rats exhibited extensive fiberosis in the all, at the first week of gestation associated with more narrowing of the uterine cavity (Fig. 11). Well implanted embryos and blood-filled spaces (Lacunae) were seen in the uterine wall during the second week of gestation, these might be related to its antioxidant activity via glutathione generation which lowered nitric oxide concentration which in turn enhances preimplantation development, delayed development and decrease inflammatory changes such as endometriosis (14). At the third week of gestation there were endomaterial hyperplasia of fibrosis of the uterine wall.

Sections of the uteri of pregnant diabetic rats treated with n-acetyl cysteine alone showed thickening of the uterine wall (due to fibrosis) and narrowing of the uterine cavity during the first week of gestation. At the second week of gestation, cavities containing well-developed embryos were seen embedded in the uterine wall. A fully differentiated embryo was seen in the third week of gestation (Fig. 12). 


\section{Lana Sardar Salih \& Kusai A .Al-Chaladi \& Hamad Jandari Jamma}

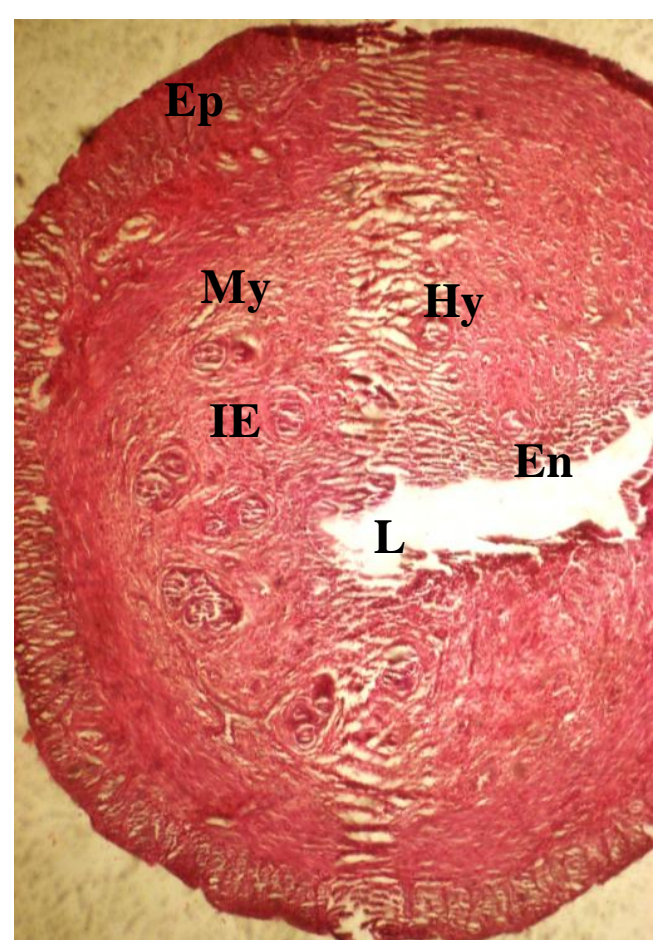

Fig. 1: Uterine section of $1^{\text {st }}$ week pregnant rats positive control ( $H$ and $E$ 24X)

En: Endometrium, Ep: Epimetrium

Hy: Hyperplasia, IE: Implant embryo

I : I Iumen. Mv: Mvometrium

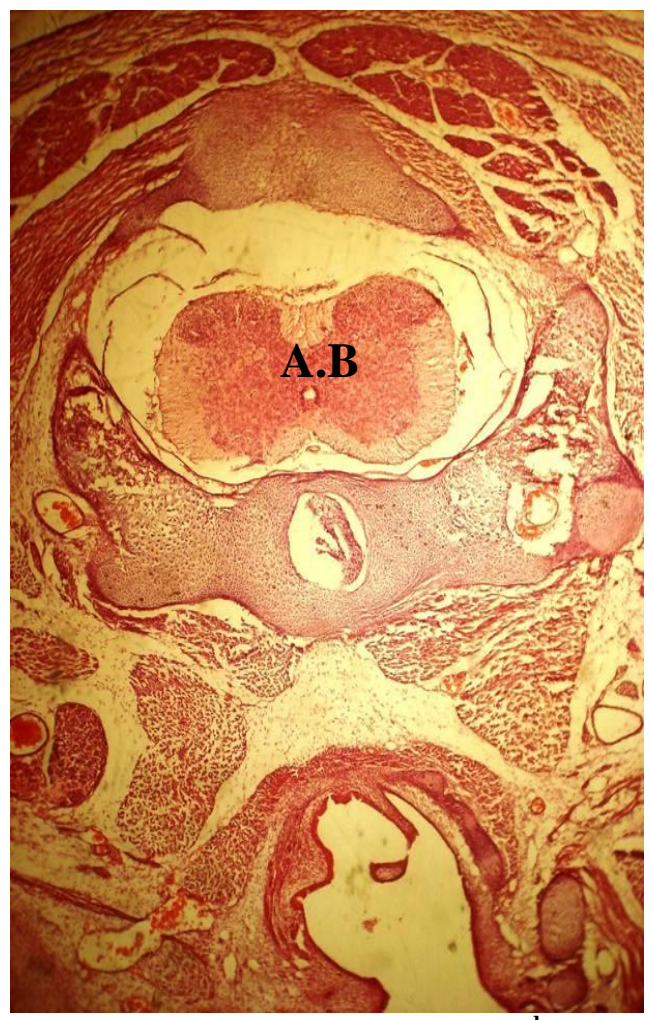

Fig. 3: Embryo section of $3^{\text {rd }}$ week pregnant rats positive control $(\mathrm{H}+\mathrm{E} 35 \mathrm{X})$

A.B: Abnormal brain

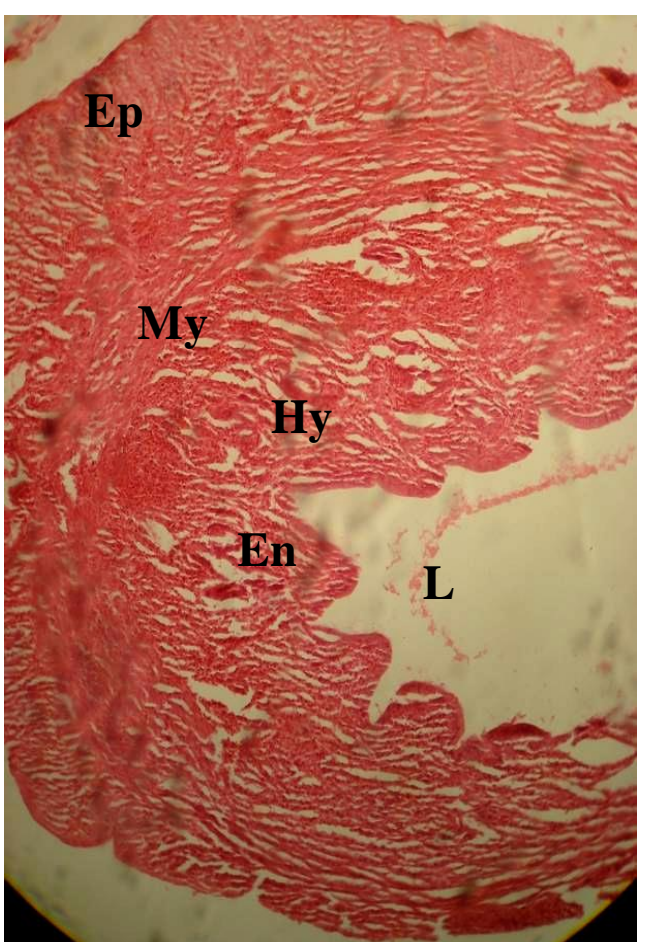

Fig. 2: Uterine section of $1^{\text {st }}$ week pregnant rats negative control (H and $\mathrm{E} 90 \mathrm{X}$ )

En: Endometrium, Ep: Epimetrium

Hy: Hyperplasia, L: Lumen,

My: Myometrium

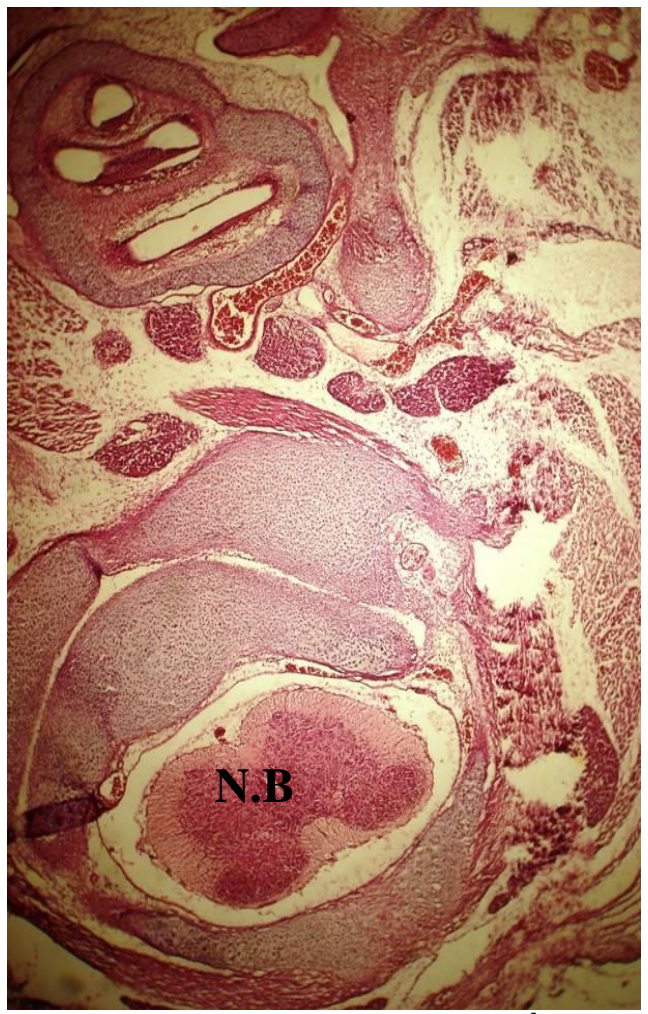

Fig. 4: Embryo section of $3^{\text {rd }}$ week pregnant rats negative control $(\mathrm{H}+\mathrm{E} 35 \mathrm{X})$

N.B: Normal Brian 
Effect of Folic Acid, N-acetyl Cysteine and Insulin and Their Combinations ...

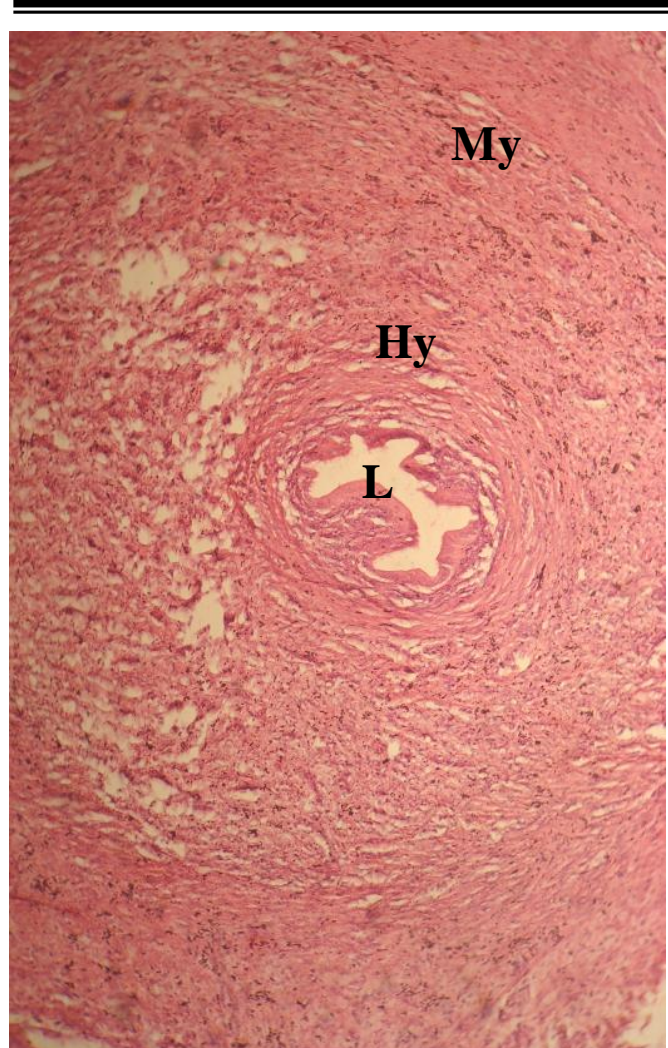

Fig. 5: Uterine section of $1^{\text {st }}$ week pregnant rats folic acid $(0.25 \mathrm{ppm})$ treated group ( $H$ and $E$ 35X)

HY: Hyperplasia, L: Lumen

My: Myometrium

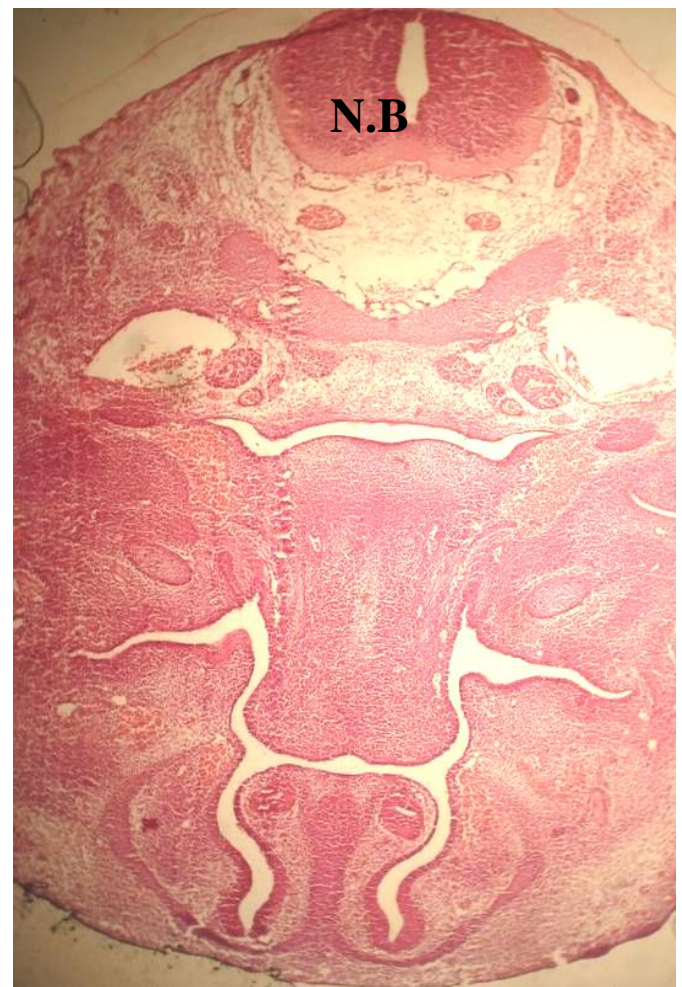

Fig. 7: Embryo section of $3^{\text {rd }}$ week pregnant rats folic acid $(7.5 \mathrm{mg} / \mathrm{kg})$ and insulin treated group ( $\mathrm{H}$ and $\mathrm{E} 35 \mathrm{X})$

N.B: Normal brain

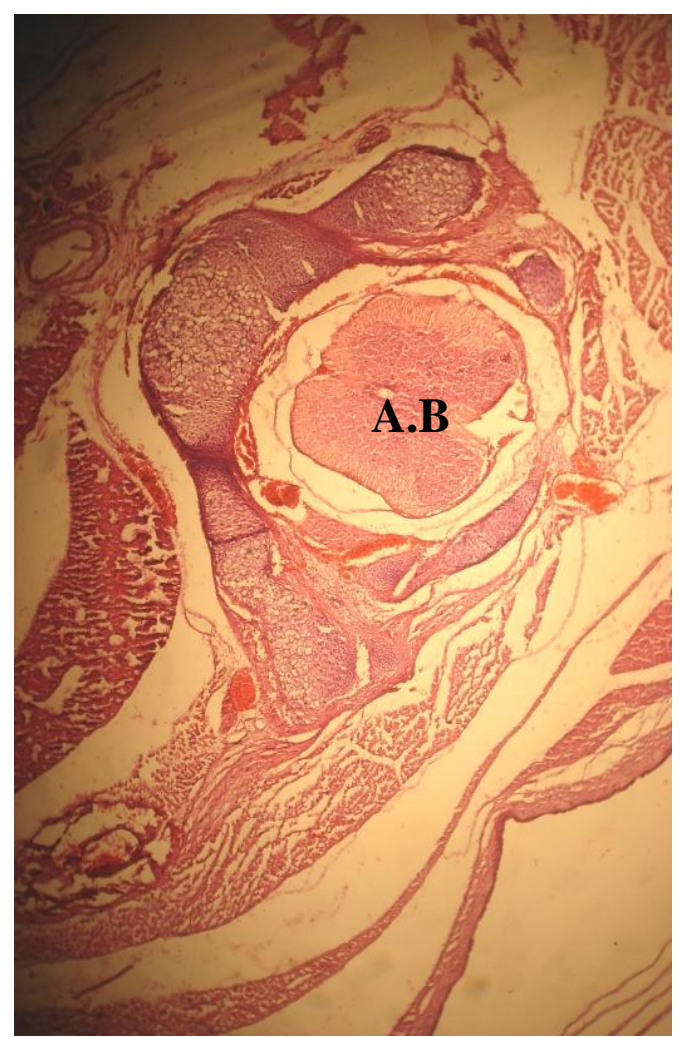

Fig. 6: Uterine section of $3^{\text {rd }}$ week pregnant rats folic acid $(0.25 \mathrm{ppm})$ treated group ( $\mathrm{H}$ and $\mathbf{E}$ 35X)

\section{A.B: Abnormal brain}

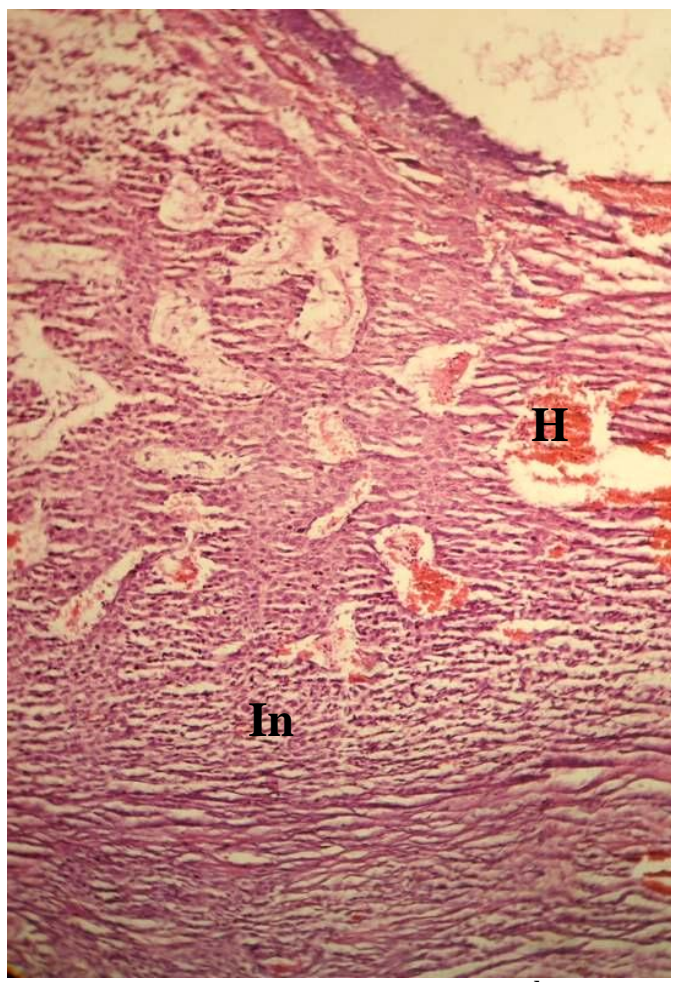

Fig. 8: Uterine section of $2^{\text {nd }}$ week pregnant rats folic acid $(0.25 \mathrm{ppm})$ treatedgroup (H and $\mathrm{E}$ 115X)

H: Hemorrhage. In: Infiltrated tissue 


\section{Lana Sardar Salih \& Kusai A .Al-Chaladi \& Hamad Jandari Jamma}

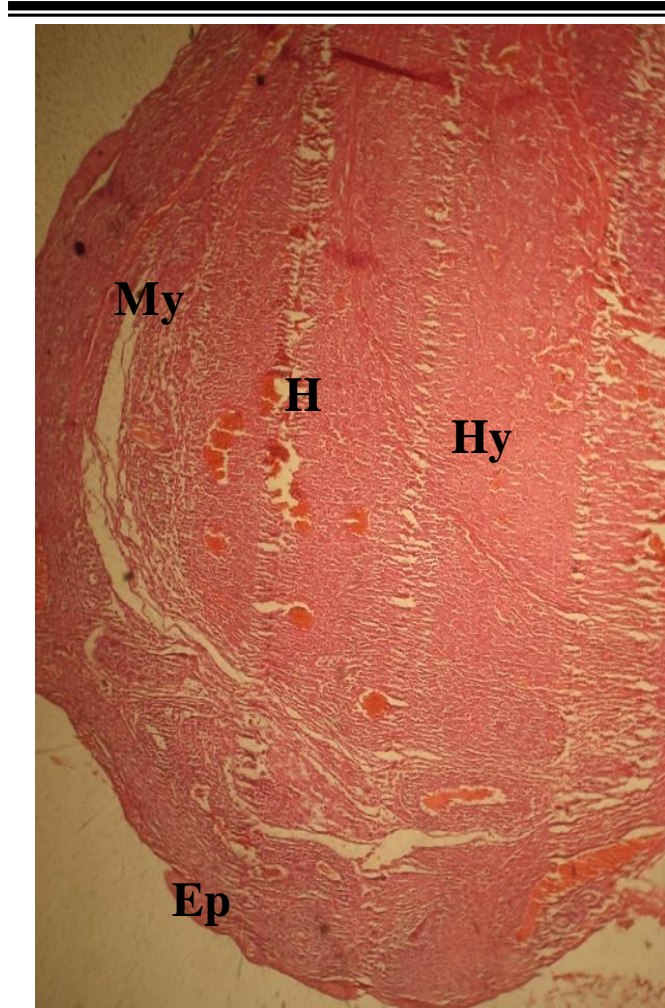

Fig. 9: Uterine section of $3^{\text {rd }}$ week pregnant rats insulin treated group ( $\mathrm{H}$ and $\mathrm{E} 35 \mathrm{X})$

Ep: Epimetrium, H: Hemorrhage

Hy: Hyperplasia, My: Myometrium

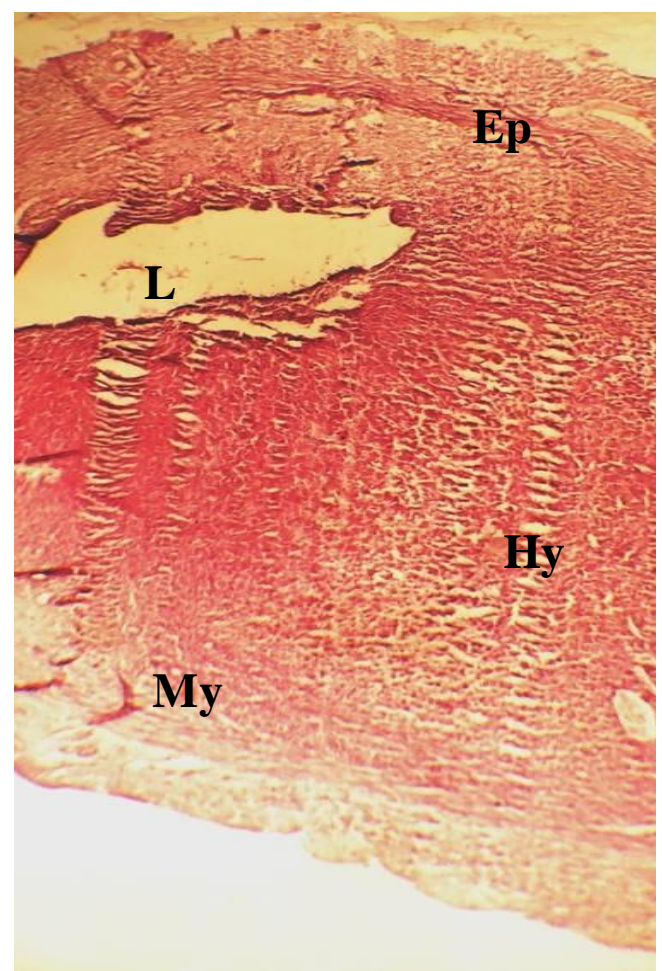

Fig. 11: Uterine section of $2^{\text {nd }}$ week pregnant rats NAC and insulin treated group (H and 24X)

Ep: Epimetrium, H: Hemorrhage

Hy: Hyperplasia, L: Lunen

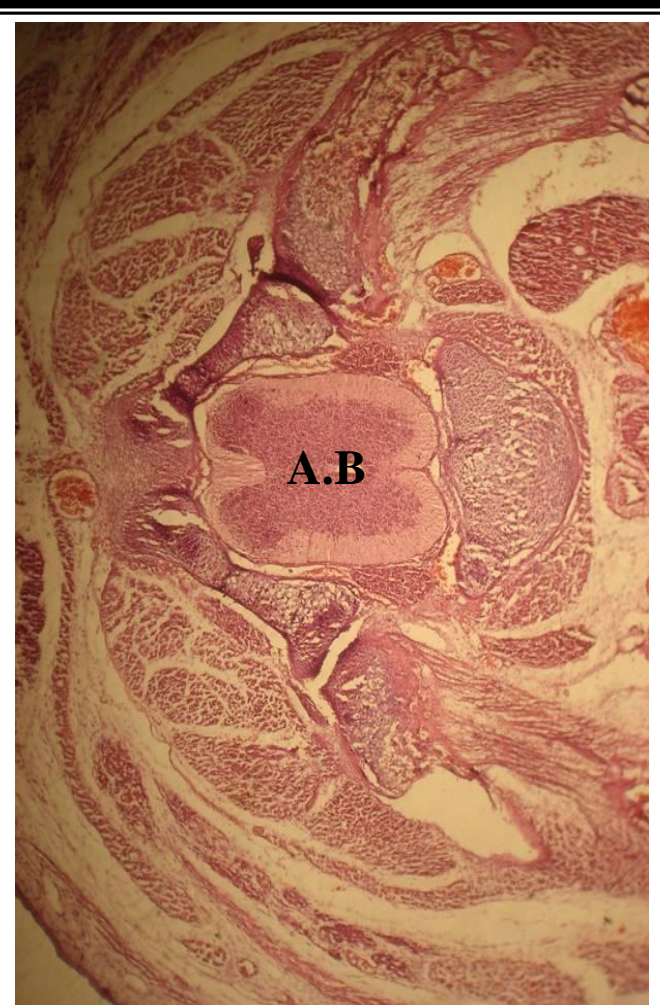

Fig. 10: Embryo section of $3^{\text {rd }}$ week pregnant rats insulin treated group $(\mathrm{H}$ and E 35X)

A.B: Abonormal brain

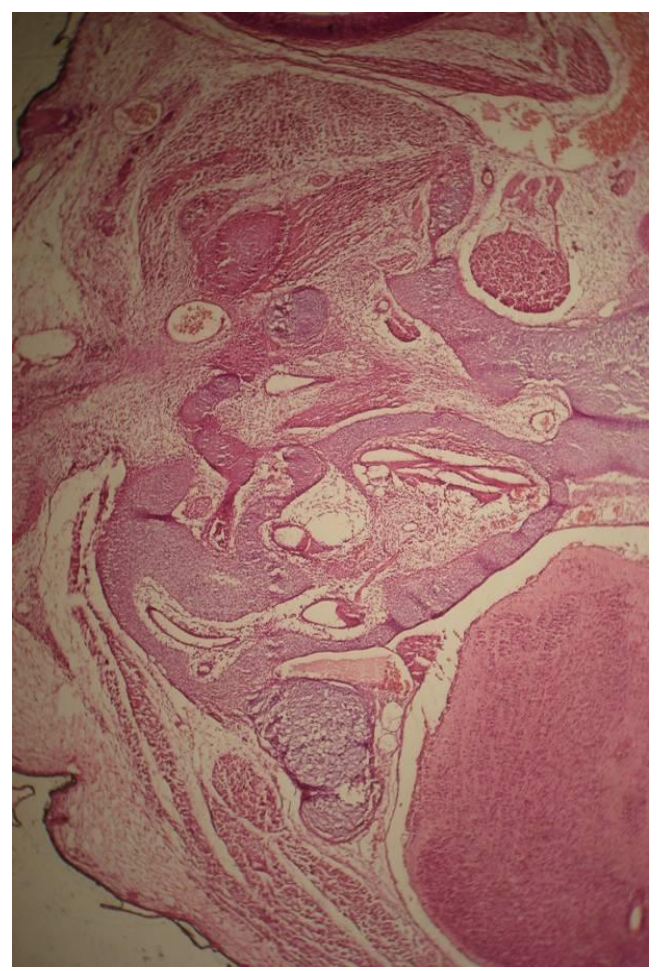

Fig. 12: Embryo section of $3^{\text {rd }}$ week pregnant rats NAC treated group ( $H$ and E 35X) 


\section{REFERENCES}

1) Colton, S. A.; Pieper, M. G. and Down, S. M. (2002). Biol. Rep., 67: 220-231.

2) Chang, A. S.; Dale, A. N. and Moley, K. H. (2005). Endocrinol., 146: 2445-2453.

3) Jansson, T., Ekstrand, Y., Bjorn, C., Wennergren, M. and Powell, T. L. (2002). Diabetes. 51: 2214-2219.

4) Kinalski, M., Sledziewski, A., Telejko, B., Kowalska, I., Zarzycki, W. and Kinalska, I. (2001). Horm. Metab. Res., 33(4): 227-231.

5) Coskun, O., Ocackci, A., Bayraktaroglu, T. and Kanter, M. (2004). Tohoku J. Exp. Med., 204: 145-154.

6) Nimenibo-Vadia, R. (2003). Trop. J. Pharmacol. Res. 2:183-189.

7) Wohaieb, S. A. and Godin, D.V. (1987). Diabetes. 36: 1014-1018 (abstract).

8) Gidado, A.; Ameh, D.A. and Atawodi, E. (2005). Afr. J. Biotechnol., 4: 9-93.

9) Bancroft, J. D. Steven, A. and Dawson, I. M. S. (1977). Edinburgh, London, New York. Churchill-Livingstone. pp.70.

10) Prophet, E. B. and Arrington, L. H. (1992). Laboratory Method in Histology. Washington DC: Armed Forces Institute of Pathology.

11) van Door, L. C.; Dijkhuizen, D. P., Kruitwagen, E. F., Heintz, A. P. and Kooi, G. S. (2004). Obstet. Gynecol., 104(3): 571-578.

12) Padmanabhan, R. and Shafiullah, M. (2001). Arch. Physiol. Biochem., 109(3): 260-271.

13) McGabin, M. D. and Zachary, J. F. (2007). Pathological Basis of Veterinary Disease. $4^{\text {th }}$ ed., Mosby Elevier. China. pp.1476.

14) Amiri, I.; Sobhani, A., Ablhassani, F., Omidinia, E., Akbari, M. and Farmani, M. (2003). Iran Biomed. J., 7(3): 107-111. 